\title{
Elektroplating Grafena-Polianilina pada Stainless Steel sebagai Elektroda pada Elektrolisis Air untuk Produksi Hidrogen
}

\section{[Electroplating of Graphene-Polyaniline on Stainless Steel as Electrodes on Water Electrolysis for Hydrogen Production]}

\author{
Rahmiani Gani*, Syarifah Rabiatul Adawiah, Arfiani Nur \\ Universitas Islam Negeri Alauddin Makassar/ Fakultas Sains dan Teknologi/Jurusan Kimia \\ JIn. H.M. Yasin Limpo No.36 Samata, Gowa, Sulawesi Selatan 90222, Indonesia
}

\begin{abstract}
Hydrogen production by water electrolysis can be optimalized by improve the working electrode. Stainless steel as working electrode was coated with graphene and polyaniline by using cyclic voltammetry method with $\mathrm{Ag} / \mathrm{AgCl}$ as reference electrode and $\mathrm{Pt}$ as counter electrode. Coated electrodes were characterized by SEM-EDS and cyclic voltammetry method. Furthermore, the synthesized electrode was applied for water electrolysis by adding 1- $5 \mathrm{~g} / \mathrm{L} \mathrm{NaHCO}_{3}$. The characterization data showed that Stainless steel/GraphenePolyaniline electrode can be synthesized by using cyclic voltammetry. The coating process was conducted at sweeping rate $10 \mathrm{mV} / \mathrm{s}$ on voltage -0.2 to $0.8 \mathrm{~V}$ for 10 cycles. The voltammograms showed that the highest cathodic peak current of electrolysis obtained at $0.491 \mathrm{~mA}$ by addition $2 \mathrm{~g} \mathrm{NaHCO}_{3}$ on SS/G-PANio,5 electrode, and the highest anodic peak current obtained at $0.191 \mathrm{~mA}$ by addition $2 \mathrm{~g} \mathrm{NaHCO}_{3}$ on SS/G-PANio,5 electrode. Based on the overpotential data, the smallest average potential difference of $\mathrm{H}^{+}$adsorption obtained by SS/G$\mathrm{PANi}_{1,0}$ electrode, and the smallest average potential difference of $\mathrm{H}^{+}$desorption obtained by SS/G-PANio,5 electrode.
\end{abstract}

Keywords: Stainless steel, hydrogen production, electroplating, electrocatalyst, electrolysis

Abstrak. Produksi hidrogen dengan elektrolisis air dapat dioptimalkan dengan memperbaiki elektroda kerja. Stainless steel sebagai elektroda kerja dilapisi dengan grafena dan polianilina menggunakan metode voltametri siklik dengan $\mathrm{Ag} / \mathrm{AgCl}$ sebagai elektroda pembanding dan $\mathrm{Pt}$ sebagai elektroda pembantu. Elektroda hasil pelapisan dikarakterisasi dengan SEM-EDS dan voltametri siklik. Selanjutnya elektroda hasil sintesis diaplikasikan untuk elektrolisis air dengan penambahan $\mathrm{NaHCO}_{3}$ 1-5 g/L. Data karakterisasi menunjukkan bahwa elektroda Stainless steel/Grafena-Polianilina dapat disintesis menggunakan voltametri siklik. Proses pelapisan dilakukan pada laju $10 \mathrm{mV} /$ detik dengan potensial $-0,2$ sampai $0,8 \mathrm{~V}$ sebanyak 10 siklus. Hasil voltamogram menunjukkan bahwa puncak arus katodik elektrolisis tertinggi diperoleh pada 0,491 mA dengan penambahan $2 \mathrm{~g}$ $\mathrm{NaHCO}_{3}$ pada elektroda SS/G-PANi 0.5 , dan puncak arus anodik tertinggi diperoleh pada 0,191 mA dengan penambahan $2 \mathrm{~g} \mathrm{NaHCO}_{3}$ pada elektroda SS/G-PANi 0 ,5. Berdasarkan data overpotensial, beda potensial ratarata terkecil adsorpsi $\mathrm{H}^{+}$diperoleh pada elektroda SS/G-PANi ${ }_{1.0}$, dan beda potensial rata-rata terkecil desorpsi $\mathrm{H}^{+}$ diperoleh pada elektroda SS/G-PANio.5.

Kata kunci: Stainless steel, produksi hidrogen, elektroplating, elektrokatalis, elektrolisis

Diterima: 14 Juni 2021, Disetujui: 20 Agustus 2021

Sitasi: Gani, R., Adawiah, S.R., dan Nur, A. (2021). Elektroplating Grafena-Polianilina pada Stainless Steel sebagai Elektroda pada Elektrolisis Air untuk Produksi Hidrogen. KOVALEN, 7(2): 109-120.

\footnotetext{
* Corresponding author

E-mail: rahmiani.gani@uin-alauddin.ac.id
} 


\section{LATAR BELAKANG}

Salah satu alternatif sumber energi selain bahan bakar dari fosil yang semakin terbatas adalah hidrogen. Hidrogen saat ini belum banyak dimanfaatkan, tetapi berpotensi sebagai pembawa energi di masa depan. Produksi hidrogen umumnya dilakukan dengan cara steam reforming dengan bahan dasar gas alam berupa gas metana (Boyano et al., 2011) atau menggunakan sumber lain seperti batu bara (Seyitoglu et al., 2017). Namun proses produksi tersebut tidak ramah lingkungan, karena selain menghasilkan hidrogen juga akan melepaskan gas $\mathrm{CO}_{2}$ ke atmosfer. Produksi hidorgen dari sumber energi terbarukan dan ramah lingkungan seperti dari biomassa (Abuadala \& Dincer, 2012), sumber biologis (Elsharnouby et al., 2013) dan air (Kelly, 2014) telah banyak diupayakan.

Gas hidrogen sebagai bahan bakar alternatif yang ramah dan aman terhadap lingkungan tidak lantas dapat diproduksi secara besar-besaran. Masalah efisiensi produk dan penyimpanan yang aman masih menjadi kendala saat ini. Elektrolisis air sebagai salah satu proses produksi hidrogen memiliki efisiensi yang lebih rendah jika dibandingkan dengan proses lain (Dincer \& Acar, 2014) dan (Okazaki \& Gotoh, 2008). Hal ini tetaplah menjadi salah satu proses produksi hidrogen yang menjanjikan dan menguntungkan terutama dari segi biaya dan dampaknya terhadap lingkungan. Oleh karena itu, perlu dibuat kondisi elektrolisis yang memungkinkan untuk memperoleh efisiensi produksi hidrogen yang tinggi.

Efisiensi kerja elektroda dalam proses elektrolisis air dapat dioptimalkan melalui pemilihan jenis elektroda yang tepat. Elektroda yang baik adalah elektroda yang tahan terhadap korosi sehingga mampu bekerja lebih lama. Elektroda yang umum digunakan untuk proses elektrolisis yaitu elektroda yang terbuat dari logam mulia seperti emas dan platinum. Namun emas dan platinum ditinjau dari segi harga termasuk logam yang mahal. Penggunaan logam selain platinum dapat menjadi salah satu alternatif baru namun kurang efektif, baik dari segi efisiensi produk maupun ketahanan dari korosi terutama jika digunakan sebagai anoda.

Stainless steel digunakan secara luas di berbagai bidang karena ketahanan korosi yang baik serta sifat mekaniknya. Dari segi harga, stainless steel ini tergolong murah dan mudah diperoleh, dan dapat digunakan sebagai elektroda pada proses elektrolisis air karena adanya sifat tahan terhadap korosi. Kemampuan tahan terhadap korosi dalam media berair berkaitan dengan kemampuannya untuk membentuk lapisan oksida pelindung yang diperkaya lapisan kromium (Okazaki \& Gotoh, 2008). Namun, lapisan oksida tersebut mengalami kerusakan di lingkungan yang mengandung klor yang menyebabkan inisisasi yang disebut korosi sumuran (pitting) (Taveira et al., 2005).

Logam selain platinum seperti stainless steel dalam penggunaanya sebagai elektroda dapat dioptimalkan dengan meningkatkan aktivitas katalitiknya. Salah satu cara untuk mengoptimalkan kerja elektroda guna memperbaiki sifat terutama aktivitas katalitiknya adalah dengan teknik pelapisan (Bard, 1983). Pelapisan dengan bahan konduktif diharapkan mampu memperbaiki sifat elektroda sehingga mampu menghasilkan efisiensi kerja yang lebih baik. Pelapisan dengan bahan lain yang bersifat konduktif 
dapat memperbaiki sifat stainless steel sebagai elektroda.

Pelapisan stainless steel dengan paduan logam Fe-Co-Ni mampu meningkatkan aktivitas katalitik pada reaksi evolusi hidrogen (Louise, 2012). Pelapisan polimer poly(ophenylenediamine) pada substrat stainless steel mampu memberikan perlindungan terhadap korosi sumuran (Dhanabal et al., 2011). Pelapisan grafena oksida tereduksi pada stainless steel secara elektrodeposisi menunjukkan perlindungan yang lebih kuat terhadap korosi dan memiliki potensi yang baik untuk diaplikasikan pada pengolahan $\mathrm{Pb}$ (II) pada air limbah (Li et al., 2017).

Salah satu polimer konduktif yang telah dikenal memeiliki banyak keunggulan yaitu polianilina. Bahan konduktif polianilina jika ditinjau dari aspek kestabilannya di udara termasuk polimer yang memiliki kestabilan paling baik diantara bahan polimer lainnya, mudah disintesis, dan memiliki konduktivitas listrikyang relatif tinggi sehingga memungkinkan untuk diproduksi secara komersil. Pelapisan polianilina pada plat stainless steel menunjukkan bahwa polianilina dapat memberikan perlindungan anodik logam pada media air korosif (Obaid et al., 2014). Sintesis Polianilina secara elektrokimia atau disebut elektropolimerisasi dianggap lebih efisien dibanding sintesis dengan cara kimia.

Grafena sejak ditemukan (Novoselov et al., 2004) hingga beberapa tahun terakhir telah banyak dimanfaatkan pada berbagai aplikasi elektrokimia, seperti baterai ion litium, layar pada perangkat elektronik, ultrakapasitor yang bekerja lebih baik daripada baterai, desalinasi air, dan masih banyak lagi (Bharech et al., 2015). Grafena memiliki banyak sifat unik yang berbeda dari bahan karbon lainnya, dikarenakan struktur dua dimensi khusus yang dimilikinya. Sifat unik yang dimaksud diantaranya memiliki luas permukaan spesifik yang tinggi, sifat elektronik dan kemampuan transpor elektron yang luar biasa serta konduktivitas termal yang tinggi (Xia et al., 2017). Pelapisan grafena pada elektroda stainless steel terbukti menghasilkan daya listrik yang lebih tinggi dibanding pelapisan dengan karbon (Hou et al., 2014).

Berdasarkan pertimbangan-pertimbangan di atas, penelitian ini mengkaji tentang sintesis elektroda stainless steel dengan pelapisan Grafena-Polianilina (G-PANi) secara voltametri serta aplikasinya sebagai elektroda elektrokatalis pada reaksi produksi hidrogen pada elektrolisis air.

\section{METODE PENELITIAN}

\section{Bahan dan Peralatan}

Adapun bahan yang digunakan adalah plat stainless steel, kertas abrasif, asam sulfat $\left(\mathrm{H}_{2} \mathrm{SO}_{4}\right)$, etanol $\left(\mathrm{C}_{2} \mathrm{H}_{6} \mathrm{O}\right)$, natrium nitrat $\left(\mathrm{NaNO}_{3}\right)$, aseton $\left(\mathrm{C}_{3} \mathrm{H}_{6} \mathrm{O}\right)$, akuades, grafit, kalium permanganat $\left(\mathrm{KMnO}_{4}\right)$, asam klorida $(\mathrm{HCl})$, asam askorbat $\left(\mathrm{C}_{6} \mathrm{H}_{8} \mathrm{O}_{6}\right)$, anilin $\left(\mathrm{C}_{6} \mathrm{H}_{5} \mathrm{NH}_{2}\right)$, hidrogen peroksida $\left(\mathrm{H}_{2} \mathrm{O}_{2}\right)$, natrium klorida $(\mathrm{NaCl})$, natrium bikarbonat $\left(\mathrm{NaHCO}_{3}\right)$.

Alat yang digunakan yaitu peralatan gelas, oven, neraca analitik, ultrasonic cleaner, sentrifus, pH meter, XRD (Shimadzu 6000), FTIR (Shimadzu Prestige 21), SEM-EDS (JEOL JSM-6510 LA), voltametri siklik (Metrohm $\mu$-AutolabIII/FRA2 potensiostat).

\section{Prosedur Penelitian}

\section{Preparasi stainless steel}

Stainless steel dibentuk seukuran $10 \times 0,5$ $\mathrm{cm}$, setelah itu dicuci dengan sabun dan dihaluskan menggunakan kertas abrasif. Kemudian digetarkan dengan ultrasonikator 
dalam larutan etanol dan aseton masingmasing selama 30 menit. Lalu dibilas dan dikeringkan dalm oven $100^{\circ} \mathrm{C}$ selama 12 jam.

\section{Sintesis grafena}

Grafit oksida disintesis dengan metode Hummers (Hummers \& Offeman, 1957) dengan grafit, $\mathrm{KMnO}_{4}, \mathrm{NaNO}_{3}$, dan $\mathrm{H}_{2} \mathrm{SO}_{4}$ sebagai bahan dasar. Grafit oksida yang diperoleh didispersikan dalam akuades dengan ultrasonikator selama 1 jam untuk membentuk dispersi grafena oksida.

Grafena disintesis dengan mereduksi grafena oksida dengan menggunakan asam askorbat. Sebanyak $50 \mathrm{~mL}$ asam askorbat ditambahkan ke dalam dispersi $0,1 \mathrm{mg} / \mathrm{mL}$ grafena oksida dalam $50 \mathrm{~mL}$ larutan. Kemudian diaduk pada suhu $80{ }^{\circ} \mathrm{C}$ selama 1,5 jam, dilanjutkan pengadukan pada suhu kamar selama 48 jam. Produk disentrifugasi, dicuci dan dikeringkan pada suhu $110{ }^{\circ} \mathrm{C}$ selama 12 jam. Grafena yang terbentuk didispersikan ke dalam akuabides dengan sonikator selama 1 jam. Karakterisasi grafena dilakukan dengan menggunakan alat XRD dan FTIR.

\section{Preparasi elektroda}

Preparasi elektroda Stainless steel/ Grafena-Polianilina (SS/G-PANi) dilakukan dengan voltametri siklik menggunakan elektroda kerja berupa plat stainless steel, elektroda pembanding berupa $\mathrm{Ag} / \mathrm{AgCl}$ dan elektroda pembantu berupa $\mathrm{Pt}$, dengan kecepatan payar sebesar $10 \mathrm{mV} /$ detik dan sebanyak 10 siklus pada tegangan antara -0,2 V - 0,8 V. Komposisi larutan untuk proses pelapisan terdiri dari grafena $1 \mathrm{mg} / \mathrm{mL}$ serta larutan untuk polimerisasi anilin yaitu larutan anilin 0,1 $\mathrm{M}$ dan larutan $\mathrm{H}_{2} \mathrm{SO}_{4}$ dengan konsentrasi 0,5 M (SS/G-PANio,5) dan 1,0 M (SS/G-PANio,1). Elektroda hasil pelapisan dikarakterisasi dengan menggunakan SEMEDS dan voltametri siklik.

\section{Proses elektrolisis}

Proses elektrolisis dengan metode voltametri siklik dengan menggunakan elektroda kerja yaitu elektroda stainless steel, elektroda stainless steel/Polianilina (SS/PANi 0,5 dan SS/PANi ${ }_{1,0}$ ) dan elektroda stainless steel/Grafena-Polianilina (SS/GPANio,5 dan SS/G-PANi ${ }_{1,0}$ ), elektroda pembanding berupa $\mathrm{Ag} / \mathrm{AgCl}$ dan elektroda pembantu berupa $\mathrm{Pt}$, dengan kecepatan payar sebesar $50 \mathrm{mV} /$ detik pada tegangan $-1,0 \mathrm{~V}$ sampai 0,2V. Selajutnya, ditambahkan $\mathrm{NaHCO}_{3}$ dengan konsentrasi 1 - $5 \mathrm{~g} / \mathrm{L}$ air pada setiap proses elektrolisis. Proses pengamatan dilakukan dengan membandingkan dan menentukan kondisi optimum masing-masing elektroda kerja.

\section{HASIL DAN PEMBAHASAN}

\section{Hasil Sintesis dan Karakterisasi Elektroda}

Karakterisasi grafena hasil sintesis dilakukan dengan XRD dan FTIR.Pengujian dengan XRD dilakukan dengan tujuan untuk mengetahui struktur grafena hasil sintesis. Pola difraksi sinar-X (Gambar 1) dari grafit murni menunjukkan puncak $2 \theta$ tertinggi yaitu 25,7888 pada $d$-spacing 3,45186 Á,sedangkan grafit oksida puncak $2 \theta$ tertinggi yaitu 10,2124 dengan $d$-spacing 8,65485 Á. Puncak $2 \theta$ tertinggi pada grafena ditunjukkan pada 24,6200 dengan d-spacing 3,61302 Á. Peningkatan $d$-spacing terjadi setelah proses oksidasi grafit menjadi grafit oksida. Hal ini disebabkan karena bertambahnya molekul air dan oksigen diantara lapisan pada grafit oksida. Penurunan $d$-spacing terjadi setelah proses pengelupasan dan reduksi menjadi grafena menandakan telah terjadinya reduksi 
gugus fungsi pada grafena oksida yang

mengecil.

menyebabkan jarak antar layer pada grafena

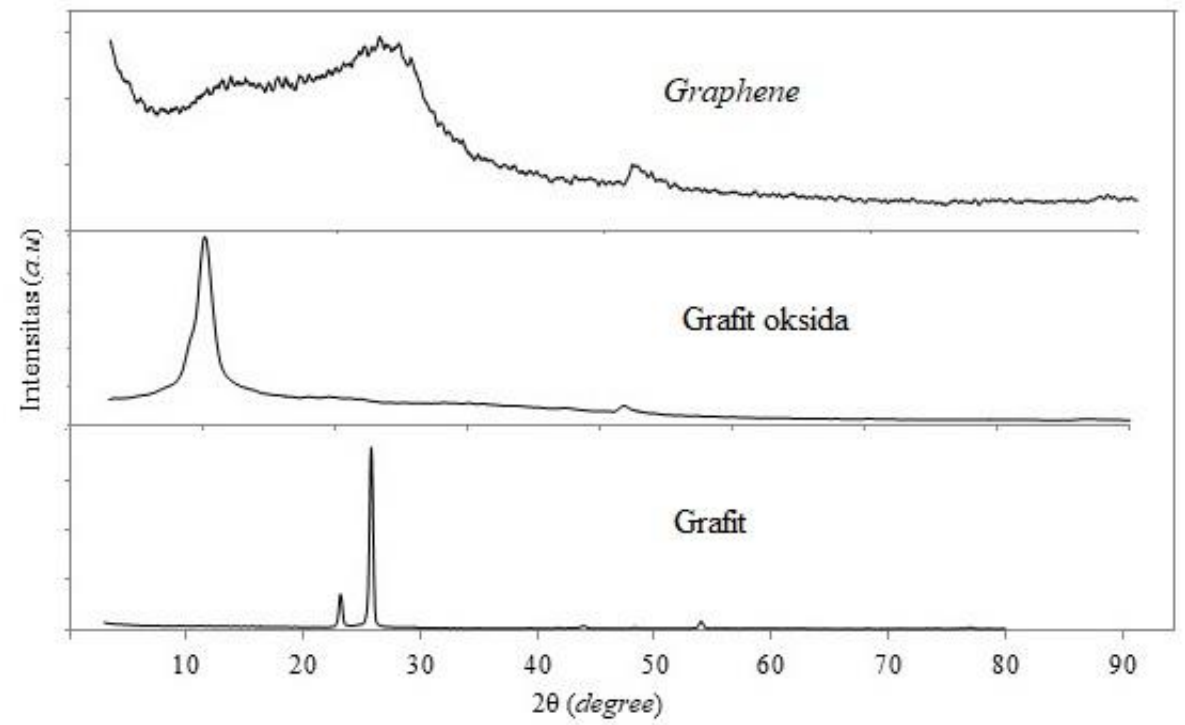

Gambar 1. Pola difraksi sinar-X grafit, grafena oksida dan grafena

Spektroskopi FTIR digunakan untuk mengetahui perubahan gugus fungsi dari grafena oksida menjadi grafena. Gambar 2 menunjukkan spektra FTIR grafena oksida dan grafena. Spektra FTIR gugus yang mengandung atom $\mathrm{O}$ pada grafena oksida ditunjukkan pada bilangan gelombang 3448,72 $\mathrm{cm}^{-1}$ yang merupakan vibrasi ulur $-\mathrm{H}$ dari gugus hidroksil -OH (pada $\mathrm{C}-\mathrm{OH}$ ), vibrasi ulur gugus $\mathrm{C}-\mathrm{O}$ pada gugus alkohol dan gugus karboksilat ditunjukan pada serapan dengan bilangan gelombang $1203,58 \mathrm{~cm}^{-1}$ dan 1126,43 $\mathrm{cm}^{-1}$. Selain itu terdapat sinyal yang lemah pada bilangan gelombang antara $1712,79 \mathrm{~cm}^{-1}$ - 1728,22 $\mathrm{cm}^{-1}$ yang merupakan vibrasi ulur $\mathrm{C}=\mathrm{O}$ gugus karboksilat dan gugus karbonil. Pada spektra grafena, intensitas serapan yang mengandung atom $\mathrm{O}$ yang ditunjukkan pada spektra grafena oksida mengalami penurunan. Hal ini menandakan telah terjadi reduksi pada grafena oksida menjadi grafena.

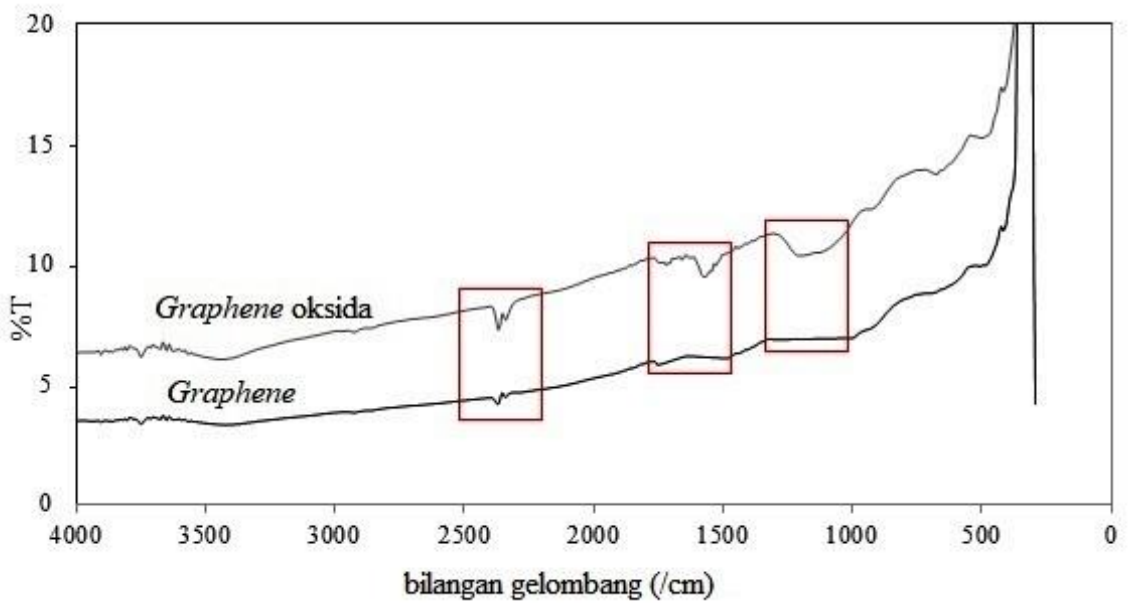

Gambar 2. Spektrum IR grafena oksida dan grafena 
Voltamogram siklik elektroda sintesis menunjukkan sinyal puncak arus oksidasi elektroda stainless steel terdeteksi pada 1,125 $\mathrm{mA}$ pada potensial 0,419 V. Elektroda Stainless steel/Polianilina yaitu elektroda SS/PANio,5 terdeteksi pada 4,993 mA pada potensial $0,461 \mathrm{~V}$ dan elektroda $\mathrm{SS} / \mathrm{PANi}_{1,0}$ pada $7,063 \mathrm{~mA}$ pada potensial $0,798 \mathrm{~V}$. Hasil ini lebih tinggi dibanding pada elektroda stainless steel tanpa pelapisan pada potensial yang lebih tinggi. Elektroda Stainless steel/Grafena-Polianilina yaitu SS/G-PANio,5 terdeteksi pada 5,082 mA pada potensial $0,527 \mathrm{~V}$ dan elektroda SS/G-PANi ${ }_{1,0}$ pada $6,313 \mathrm{~mA}$ pada potensial $0,520 \mathrm{~V}$. Arus oksidasi ini lebih kuat dan lebih tinggi menandakan telah terjadi proses pelapisan pada permukaan elektroda sehingga kemampuan oksidasi elektroda lebih baik.

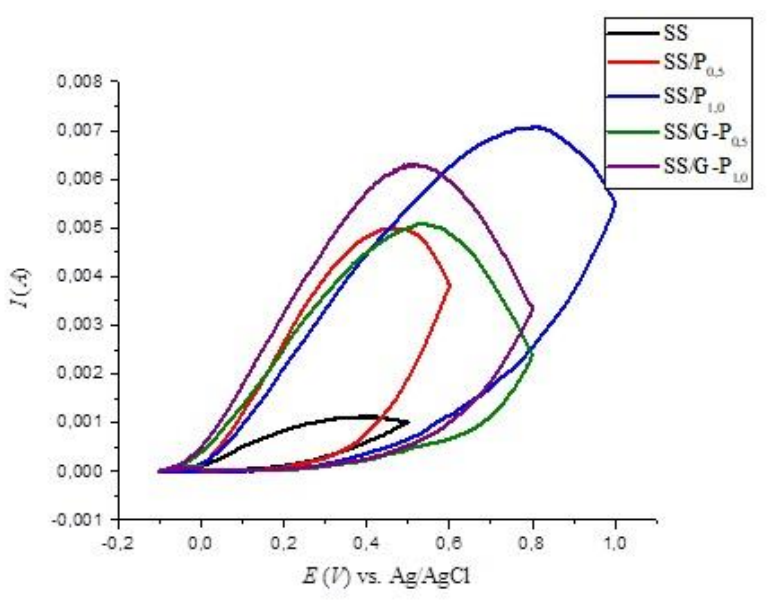

Gambar 3. Voltamogram siklik elektroda hasil pelapisan

Foto SEM stainless steel sebelum banyak bercak dibanding pada elektroda pelapisan ditunjukkan pada Gambar 4, tidak stainless steel, sedangkan pada elektroda terlihat bercak pada permukaan elektroda menunjukkan belum terjadi proses pelapisan. $\mathrm{SS} / \mathrm{PANi}_{1,0}$ bercak yang dihasilkan lebih sedikit dibanding pada elektroda SS/PANio,5.

Pada elektroda SS/PANio,5 dihasilkan lebih
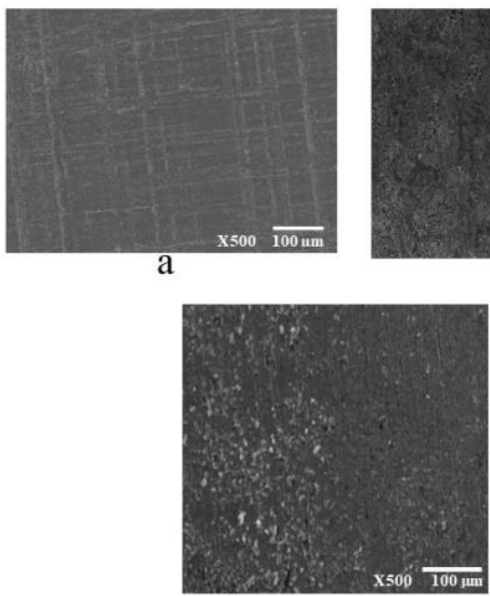

d

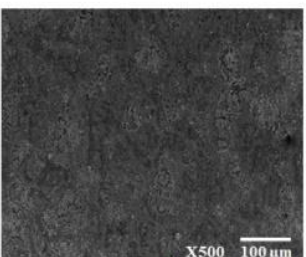

$\mathrm{b}$

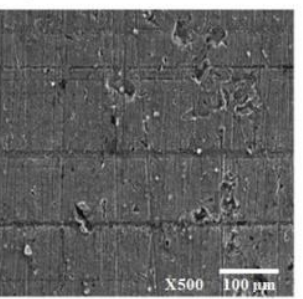

$\mathrm{C}$

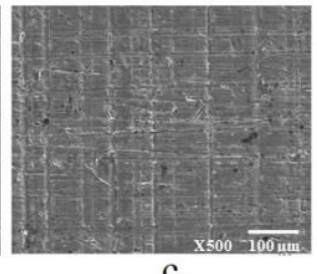

c

Gambar 4. Foto SEM elektroda (a) Stainless steel, (b) SS/PANio,5, (c) SS/PANi ${ }_{1,0}$, (d) SS/G-PANi $i_{0,5}$ dan (e) SS/G-PANi ${ }_{1,0}$ 
Hasil di atas menunjukkan telah terjadi pelapisan polianilina pada permukaan stainless steel. Pada elektroda SS/G-PANio,5 dihasilkan bercak lebih banyak dan lebih merata dibanding pada elektroda stainless steel, sedangkan pada elektroda SS/G-PANi ${ }_{1,0}$ bercak yang dihasilkan lebih sedikit dibanding pada elektroda SS/G-PANio,5. Hasil ini menunjukkan telah terjadi pelapisan grafena dan polianilina pada permukaan stainless steel.

\section{Aplikasi Elektroda Hasil Pelapisan}

Proses elektrolisis dilakukan dengan elektroda hasil sintesis sebagai elektroda kerja. Puncak arus katodik ( $\mathrm{i}_{\mathrm{c}}$ ) dan anodik ( $\mathrm{i}_{\mathrm{a}}$ ) tertinggi elektroda stainless steel dapat dilihat masing-masing pada penambahan $2 \mathrm{~g}$ $\mathrm{NaHCO}_{3}$. Pada puncak arus katodik menunjukkan angka 0,368 $\mathrm{mA}$ dengan potensial sebesar $-0,839 \mathrm{~V}$, sedangkan puncak arus anodik menunjukkan angka 0,089 $\mathrm{mA}$ dengan potensial sebesar -0,256 V. Tujuan penambahan $\mathrm{NaHCO}_{3}$ ialah untuk mengkatalisis molekul $\mathrm{H}_{2} \mathrm{O}$ melalui proses elektrokimia.

Jumlah $\mathrm{H}^{+}$yang teradsorpsi pada permukaan elektroda berbanding lurus dengan puncak arus katodik, begitu juga dengan jumlah $\mathrm{H}^{+}$yang terdesorpsi pada permukaan elektroda berbanding lurus dengan puncak arus anodik. Secara fisik, pada proses elektrolisis terdapat gelembung gas teramati pada permukaan elektroda. Pada elektroda tanpa pelapisan, gelembung gas yang teramati sangat sedikit dan segera menghilang. Gelembung gas lebih banyak teramati pada elektrolisis dengan elektroda hasil perlapisan.

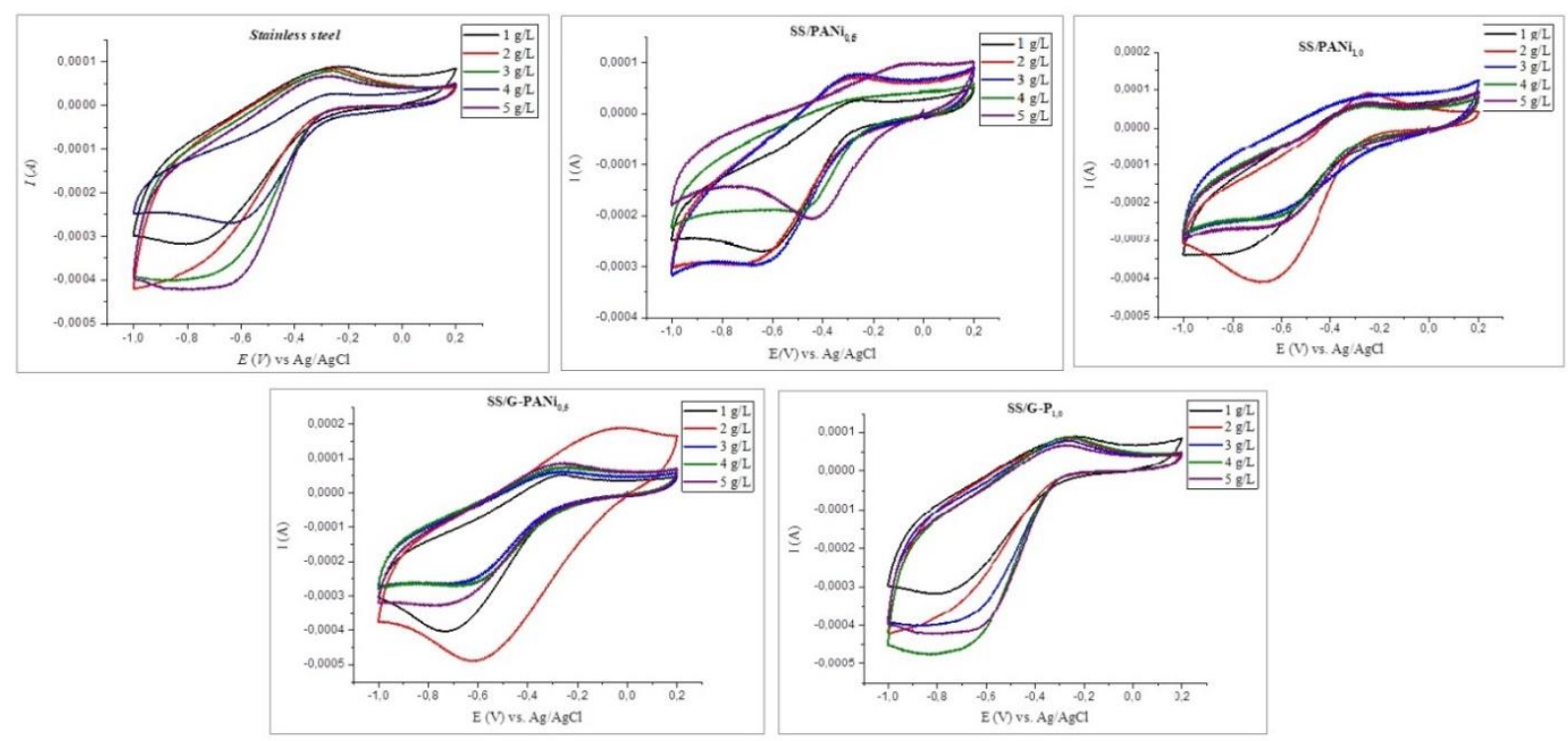

Gambar 5. Voltamogram elektroda hasil elektrolisis dengan penambahan $\mathrm{NaHCO}_{3} \quad 1-5 \mathrm{~g} / \mathrm{L}$ air (kecepatan payar $50 \mathrm{mV} / \mathrm{s}$ pada siklus pertama)

Puncak arus katodik dan anodik tertinggi pada elektroda hasil sitensis menunjukkan hasil yang lebih baik dibanding tanpa pelapisan. Puncak arus katodik (ic) tertinggi yaitu pada elektroda $\mathrm{SS} / \mathrm{PANi}_{0,5}$ dapat dilihat pada penambahan 1 g $\mathrm{NaHCO}_{3}$ yang menunjukkan angka sebesar 0,455 mA dengan potensial sebesar $-0,679 \mathrm{~V}$. Pada elektroda SS/PANi $i_{1,0}$ diperoleh pada penambahan $2 \mathrm{~g} \mathrm{NaHCO}_{3}$ yaitu sebesar 0,411 $\mathrm{mA}$ pada potensial $-0,669 \mathrm{~V}$. Elektroda SS/G$\mathrm{P}_{0,5}$ diperoleh pada penambahan $2 \mathrm{~g} \mathrm{NaHCO}_{3}$ 
sebesar 0,491 mA dengan potensial -0,620 V. Elektroda $S S / G-P_{1,0}$ pada penambahan $4 \mathrm{~g}$ $\mathrm{NaHCO}_{3}$ sebesar 0,477 mA potensial -0,825 V.

Puncak arus anodik ( $\mathrm{i}_{\mathrm{a}}$ ) tertinggi pada elektroda SS/PANi ${ }_{0,5}$ diperoleh pada penambahan $5 \mathrm{~g} \mathrm{NaHCO}_{3}$ yang menunjukkan angka 0,093 mA dengan potensial sebesar 0,033 V. Pada elektroda SS/PANi ${ }_{1,0}$ diperoleh pada penambahan $2 \mathrm{~g} \mathrm{NaHCO}$ yaitu sebesar 0,090 mA pada potensial -0,242 V. Elektroda $\mathrm{SS} / \mathrm{G}-\mathrm{P}_{0,5}$ diperoleh pada penambahan $2 \mathrm{~g}$ $\mathrm{NaHCO}_{3}$ sebesar 0,191 mA pada potensial 0,019 V. Elektroda SS/G-P ${ }_{1,0}$ diperoleh pada penambahan $1 \mathrm{~g} \mathrm{NaHCO}_{3}$ sebesar 0,091 mA pada potensial $-0,229 \mathrm{~V}$.

\section{Kondisi Optimum Elektroda}

Penentuan kondisi optimum suatu elektroda bertujuan untuk menunjukkan kondisi elektrolisis air dimana hidrogen yang dihasilkan paling optimum atau dengan kata lain menunjukkan efektivitas elektroda yang paling baik. Kondisi optimum ini dapat ditentukan berdasarkan puncak arus katodik (ipc) dan anodik (i $\mathrm{i}_{\mathrm{pa}}$ ) yang disebut rendemen arus atau rendemen Faraday, serta rendemen energi yang diperoleh dari beda potensial elektroda dalam reaksi elektrolisis. Penentuan besarnya efektivitas elektroda untuk rendemen Faraday diperoleh dari persamaan (1) dan (2), yang didasarkan pada jumlah adsorpsi $\mathrm{H}^{+}$pada permukaan elektroda dan jumlah $\mathrm{H}^{+}$ terdesorpsi dari permukaan elektroda yaitu pelepasan $\mathrm{H}_{2}$ (Louise, 2012).

$$
\begin{aligned}
& \varepsilon_{\mathrm{H}}=\frac{\mathrm{i}_{\mathrm{pc}, \text { elektroda sintesis }}}{i_{\mathrm{pc} \text {,stainless steel }}} \\
& \varepsilon_{\mathrm{H}^{+}}=\frac{\mathrm{i}_{\text {pa,elektroda sintesis }}}{\mathrm{i}_{\text {pa,stainless steel }}}
\end{aligned}
$$

\footnotetext{
Keterangan:

$\varepsilon_{\mathrm{H}}=$ Efisiensi adsorpsi $\mathrm{H}^{+}$ $\varepsilon_{\mathrm{H}^{+}}=$Efisiensi desorpsi $\mathrm{H}^{+}$
}

$\mathrm{i}_{\mathrm{pc}}=$ Arus puncak katodik

$\mathrm{i}_{\mathrm{pa}}=$ Arus puncak anodik

Semakin besar nilai $\varepsilon_{\mathrm{H}}$ dan $\varepsilon_{\mathrm{H}^{+}}$menandakan sifat katalitik elektroda dalam adsorpsi-desorpsi $\mathrm{H}^{+}$lebih baik jika dibandingkan dengan elektroda sebelum pelapisan, yang berarti bahwa kemampuan produksi hidrogen juga lebih optimum.

Rendemen energi dapat dihitung berdasarkan besarnya energi yang diperlukan pada proses produksi hidrogen. Hal ini ditunjukkan dengan melihat selisih antara potensial yang dibutuhkan dalam eksperimen dengan potensial teoritik $(\Delta \mathrm{V})$ sesuai dengan persamaan (3):

$$
\Delta \mathrm{V}=\mathrm{E}_{\mathrm{ekp}}-\mathrm{E}_{\text {teori }}
$$

Potensial teoritik dapat dihitung berdasarkan persamaan (Bard, 1983):

$$
\begin{aligned}
& E_{\text {red }}=-0,059 \times \mathrm{pH} \\
& E_{\text {oks }}=(-0,197-0,059) \times p H
\end{aligned}
$$

Keterangan:

$$
\begin{array}{ll}
E_{\text {red }} & =\text { Potensial reduksi } \\
E_{\text {oks }} & =\text { Potensial oksidasi }
\end{array}
$$

Pengukuran potensial eksperimental dapat diperolehdari data voltametri siklik yang didasarkan pada besaran potensial adsorpsi dan potensial desorpsi hidrogen dalam reaksi elektrolisis. Efektivitas elektroda ditunjukkan dengan melihat rendemen energi yang relatif paling kecil.

Puncak arus anodik dan katodik paling tinggi untuk elektroda sebelum pelapisan diperoleh pada penambahan $2 \mathrm{~g} \mathrm{NaHCO}_{3}$ masing-masing sebesar 0,089 mA dan 0,368 mA. Pada elektroda sintesis SS/PANi ${ }_{0,5}$ diperoleh pada penambahan $\mathrm{NaHCO}_{3}$ masingmasing $5 \mathrm{~g}$ dan $1 \mathrm{~g}$ sebesar 0,093 $\mathrm{mA}$ dan 0,455 mA. Elektroda SS/PANi ${ }_{1,0}$ diperoleh pada 
penambahan $\mathrm{NaHCO}_{3} 2 \mathrm{~g}$ sebesar $0,090 \mathrm{~mA}$ dan $0,411 \mathrm{~mA}$. Elektroda SS/G-PANio,5 pada penambahan $\mathrm{NaHCO}_{3} 2 \mathrm{~g}$ sebesar $0,191 \mathrm{~mA}$ dan $0,491 \mathrm{~mA}$. Elektroda $\mathrm{SS} / \mathrm{G}-\mathrm{PANi} \mathrm{i}_{0,5}$ pada penambahan $\mathrm{NaHCO}_{3}$ masing-masing $1 \mathrm{~g}$ dan $4 \mathrm{~g}$ sebesar 0,091 mA dan 0,477 mA.

Tabel 1. Rasio arus puncak elektroda sintesis terhadap elektroda tanpa pelapisan

\begin{tabular}{ccccccccc}
\hline \multirow{2}{*}{$\begin{array}{c}\mathrm{NaHCO}_{3}(\mathrm{~g} / \mathrm{L} \\
\text { air })\end{array}$} & \multicolumn{2}{c}{$\mathrm{SS} / \mathrm{PANi}_{0,5}$} & \multicolumn{2}{c}{ SS/PANi ${ }_{1,0}$} & \multicolumn{2}{c}{ SS/G-PANi, 5} & \multicolumn{2}{c}{ SS/G-PANi ${ }_{1,0}$} \\
\cline { 2 - 9 } & $\mathrm{i}_{\mathrm{pc}}$ & $\mathrm{i}_{\mathrm{pa}}$ & $\mathrm{i}_{\mathrm{pc}}$ & $\mathrm{i}_{\mathrm{pa}}$ & $\mathrm{i}_{\mathrm{pc}}$ & $\mathrm{i}_{\mathrm{pa}}$ & $\mathrm{i}_{\mathrm{pc}}$ & $\mathrm{i}_{\mathrm{pa}}$ \\
\hline 1 & 1,740 & 1,216 & 1,710 & 1,231 & 2,020 & 1,039 & 1,595 & 1,784 \\
2 & 0,807 & 0,820 & 1,334 & 2,146 & 1,117 & 1,011 & 1,147 & 0,978 \\
3 & 0,657 & 0,888 & 0,633 & 0,989 & 0,587 & 0,359 & 0,886 & 0,910 \\
4 & 0,712 & 2,107 & 0,904 & 2,107 & 1,192 & 1,643 & 1,760 & 3,214 \\
5 & 0,696 & 1,148 & 0,899 & 0,827 & 1,104 & 1,099 & 1,418 & 0,852 \\
\hline
\end{tabular}

Tabel 1 menunjukkan rasio arus puncak elektroda sintesis relatif terhadap elektroda stainless steel tanpa pelapisan. Semakin besar nilai rasio arus puncak, maka sifat katalitik elektroda sintesis lebih baik. Rasio arus puncak katodik terbesar diperoleh pada elektroda SS/G-PANio,5 pada penambahan $1 \mathrm{~g}$ $\mathrm{NaHCO}_{3}$ sebesar 2,020 dan rasio arus puncak anodik terbesar diperoleh pada elektroda
SS/G-PANi $1_{1,0}$ pada penambahan $4 \mathrm{~g} \mathrm{NaHCO}_{3}$ sebesar3,214.

Perbandingan perhitungan potensial adsorpsi dan desorpsi $\mathrm{H}^{+}$ditunjukkan pada Tabel 2 berdasarkan persamaan (4) dan persamaan (5). Hasil ini digunakan untuk perhitungan selanjutnya untuk menghitung besar beda potensial $(\Delta \mathrm{V})$ elektroda.

Tabel 2. Pontesial adsorpsi $\mathrm{H}^{+}\left(E_{\text {red }}\right)$ dan potensial desorpsi $\mathrm{H}^{+}$(Eoks) teoritik

\begin{tabular}{lcccc}
\hline No. & $\begin{array}{c}\mathrm{NaHCO}_{3} \\
(\mathrm{~g} / \mathrm{L} \text { air })\end{array}$ & $\mathrm{pH}$ & $\begin{array}{c}\text { Ered teoritik terhadap } \\
\mathrm{Ag} / \mathrm{AgCl}(\mathrm{V})\end{array}$ & $\begin{array}{c}\text { Eoks teoritik terhadap } \\
\mathrm{Ag} / \mathrm{AgCl}(\mathrm{V})\end{array}$ \\
\hline 1. & 1 & 8,5 & $-0,501$ & 0,729 \\
2. & 2 & 8,7 & $-0,513$ & 0,717 \\
3. & 3 & 8,7 & $-0,513$ & 0,717 \\
4. & 4 & 8,9 & $-0,525$ & 0,705 \\
5. & 5 & 8,9 & $-0,525$ & 0,705 \\
\hline
\end{tabular}

Tabel 3 memperlihatkan besaran beda potensial $(\Delta \mathrm{V})$ elektroda. Semakin kecil harga beda potensial menunjukkan energi yang dibutuhkan untuk terjadinya reaksi menjadi lebih sedikit sehingga akan lebih efektif dalam produksi hidrogen. Hasil menunjukkan elektroda SS/G-PANi ${ }_{1,0}$ memiliki kemampuan katalitik terhadap adsorpsi $\mathrm{H}^{+}$lebih baik dibanding elektroda lainnya, sedangkan elektroda $\mathrm{SS} / \mathrm{PANi}_{0,5}$ memiliki kemampuan katalitik terhadap desorpsi $\mathrm{H}^{+}$lebih baik dibanding elektroda lainnya. 
Tabel 3. Potensial adsorpsi $\left(E_{R}\right)$ dan desorpsi $\mathrm{H}^{+}\left(E_{O}\right)$ berdasarkan voltamogram siklik (eksperimen) serta beda potensial ekperimen dan teoritik $(\Delta \mathrm{V})$

\begin{tabular}{|c|c|c|c|c|c|c|}
\hline \multirow{2}{*}{ No. } & \multirow{2}{*}{ Elektroda kerja } & \multirow{2}{*}{$\begin{array}{c}\mathrm{NaHCO}_{3} \\
\text { (g/L air) }\end{array}$} & \multicolumn{2}{|c|}{$\mathrm{E}_{\mathrm{R}}$ terhadap $\mathrm{Ag} / \mathrm{AgCl}$} & \multicolumn{2}{|c|}{ Eo terhadap $\mathrm{Ag} / \mathrm{AgCl}$} \\
\hline & & & $\mathrm{E}_{\text {Reksp }}(\mathrm{V})$ & $\Delta \mathrm{E}(\mathrm{V})$ & E & $\Delta \mathrm{E}(\mathrm{V})$ \\
\hline \multirow{5}{*}{1.} & \multirow{5}{*}{ SS } & 1 & $-0,742$ & $-0,241$ & $-0,256$ & $-0,958$ \\
\hline & & 2 & $-0,839$ & $-0,362$ & $-0,256$ & $-0,973$ \\
\hline & & 3 & $-0,789$ & $-0,276$ & 0,193 & $-0,524$ \\
\hline & & 4 & $-0,637$ & $-0,112$ & $-0,263$ & $-0,968$ \\
\hline & & 5 & $-0,869$ & $-0,344$ & $-0,234$ & $-0,939$ \\
\hline \multirow{5}{*}{2.} & \multirow{5}{*}{$\mathrm{SS} / \mathrm{PANi}_{0,5}$} & 1 & $-0,679$ & $-0,178$ & $-0,259$ & $-0,988$ \\
\hline & & 2 & $-0,807$ & $-0,294$ & $-0,820$ & $-1,537$ \\
\hline & & 3 & $-0,657$ & $-0,144$ & $-0,888$ & $-1,605$ \\
\hline & & 4 & $-0,712$ & $-0,187$ & $-2,107$ & $-2,812$ \\
\hline & & 5 & $-0,696$ & $-0,171$ & $-1,148$ & $-1,853$ \\
\hline \multirow{5}{*}{3.} & \multirow{5}{*}{$\mathrm{SS} / \mathrm{PANi}_{1,0}$} & 1 & $-0,994$ & $-0,493$ & $-0,244$ & $-0,973$ \\
\hline & & 2 & $-0,669$ & $-0,156$ & $-0,242$ & $-0,959$ \\
\hline & & 3 & $-1,001$ & $-0,488$ & $-0,206$ & $-0,923$ \\
\hline & & 4 & $-0,679$ & $-0,154$ & $-0,260$ & $-0,965$ \\
\hline & & 5 & $-0,750$ & $-0,225$ & $-0,233$ & $-0,938$ \\
\hline \multirow{5}{*}{4.} & \multirow{5}{*}{$\mathrm{SS} / \mathrm{G}-\mathrm{PANi} 0,5$} & 1 & $-0,729$ & $-0,228$ & $-0,259$ & $-0,988$ \\
\hline & & 2 & $-0,620$ & $-0,107$ & $-0,019$ & $-0,736$ \\
\hline & & 3 & $-0,588$ & $-0,075$ & $-0,251$ & $-0,968$ \\
\hline & & 4 & $-0,547$ & $-0,022$ & $-0,234$ & $-0,939$ \\
\hline & & 5 & $-0,784$ & $-0,259$ & $-0,266$ & $-0,971$ \\
\hline \multirow{5}{*}{5.} & \multirow{5}{*}{$\mathrm{SS} / \mathrm{G}-\mathrm{PANi} \mathrm{1}_{1,0}$} & 1 & $-0,810$ & $-0,309$ & $-0,229$ & $-0,958$ \\
\hline & & 2 & $-0,998$ & $-0,485$ & $-0,256$ & $-0,973$ \\
\hline & & 3 & $-0,839$ & $-0,326$ & $-0,263$ & $-0,980$ \\
\hline & & 4 & $-0,825$ & $-0,300$ & $-0,253$ & $-0,958$ \\
\hline & & 5 & $-0,781$ & $-0,256$ & $-0,258$ & $-0,963$ \\
\hline
\end{tabular}

Secara umum, proses pelapisan grafena dan polianilina pada stainless steel telah mampu memperbaiki kemampuan elektrokatalitik pada stainless steel terhadap adsorpsi atau desorpsi $\mathrm{H}^{+}$. Berdasarkan rendemen arus, elektroda SS/G-PANio,5 memiliki kemampuan katalitik terhadap adsorpsi-desorpsi $\mathrm{H}^{+}$lebih baik dibanding elektroda lainnya, sedangkan rendemen energi menunjukkan elektroda SS/G-PANi $i_{1,0}$ memiliki kemampuan katalitik terhadap adsorpsi $\mathrm{H}^{+}$dan elektroda SS/G-PANio,5 memiliki kemampuan katalitik terhadap desorpsi $\mathrm{H}^{+}$lebih baik dibanding elektroda lainnya.

\section{KESIMPULAN}

Puncak arus katodik tertinggi pada elektroda SS/G-PANi ${ }_{0,5}$ dan $\quad$ SS/G-PANi ${ }_{1,0}$ 
mengalami peningkatan dibanding elektroda yang lain masing-masing pada penambahan 3 g $\mathrm{NaHCO}_{3}$ sebesar 0,491 mA dan penambahan $2 \mathrm{~g} \mathrm{NaHCO}_{3}$ sebesar 0,477 mA. Kondisi optimum diperoleh pada elektroda $\mathrm{SS} / \mathrm{G}-\mathrm{PANi}_{0,5}$ yaitu pada penambahan $2 \mathrm{~g}$ $\mathrm{NaHCO}_{3}$. Hasil rendemen arus menunjukkan elektroda SS/G-PANio,5 memiliki kemampuan katalitik adsorpsi-desorpsi $\mathrm{H}^{+}$lebih baik. Sedangkan berdasakan rendemen energi, elektroda SS/G-PANio,5 memiliki kemampuan katalitik adsorpsi $\mathrm{H}^{+}$dan elektroda SS/PANio,5 memiliki kemampuan katalitik desorpsi $\mathrm{H}^{+}$lebih baik dibanding elektroda lainnya.

\section{DAFTAR PUSTAKA}

Abuadala, A., dan Dincer, I. (2012). A Review on Biomass Based Hydrogen Production and Potential Applications. International Journal of Energy Research, 36(4): 415455. https://doi.org/10.1002/er.1939

Bard, A. J. (1983). Chemical Modification of Electrodes. Journal of Chemical Education, 60(4): 302-304. https://doi.org/10.1021/ed060p302

Bharech, S. dan Kumar, R. (2015). A Review on the Properties and Applications of Graphene. Journal of Material Science and Mechanical Engineering (JMSME), 2(10): 70-73.

Boyano, A., Blanco-Marigorta, A. M., Morosuk, T., dan Tsatsaronis, G. (2011). Exergoenvironmental Analysis of a Steam Methane Reforming Process for Hydrogen Production. Energy, 36(4): 2202-2214.

https://doi.org/10.1016/j.energy.2010.05. 020

Dhanabal, T., Amirthaganesan, G., dan Ravichandran, J. (2011). Pitting Corrosion Protection of Low Nickel Stainless Steel by Electropolymerized Conducting Polymer Coating in $0.5 \mathrm{M}$ $\mathrm{NaCl}$ Solution. Bulletin of Materials Science, 34(3): 563-569.

Dincer, I., dan Acar, C. (2014). Review and Evaluation of Hydrogen Production
Methods for Better Sustainability. International Journal of Hydrogen Energy, 40(34): 11094-11111. https://doi.org/10.1016/j.ijhydene.2014.12 .035

Elsharnouby, O., Hafez, H., Nakhla, G., dan El Naggar, M. H. (2013). A Critical Literature Review on Biohydrogen Production by Pure Cultures. International Journal of Hydrogen Energy, 38(12): 4945-4966. https://doi.org/10.1016/j.ijhydene.2013.02 .032

Hou, J., Liu, Z., Li, Y., dan Yang, S. (2014). A Comparative Study of Graphene-Coated Stainless Steel Fiber Felt and Carbon Cloth as Anodes in MFCs. Journal of Bioprocess and Biosystem Engineering, 38(5), https://doi.org/10.1007/s00449014-1332-0

Hummers, WS dan Offeman, R. (1957). Preparation of Graphitic Oxide. Journal of the American Chemical Society, 208(1937), https://doi.org/10.1021/ja01539a017

K.S. Novoselov, A. K. Geim, S. V. Morozov, D. Jiang, Y. Zhang, S.V. Dubonos, I. V., dan Grigorieva, A. A. F. (2004). Electric Field Effect in Atomically Thin Carbon Films. Science, 306: 666-669.

Kelly, N. A. (2014). Hydrogen Production by Water Electrolysis. Advances in Hydrogen Production, Storage and Distribution, $\quad$ 159-185. https://doi.org/10.1533/9780857097736.2 .159

Li, X., Li, H., Xu, X., Guo, N., Yuan, L., dan Yu, H. (2017). Preparation of A Reduced Graphene Oxide@ @tainless Steel Net Electrode and Its Application of Electrochemical Removal Pb (II). Journal of The Electrochemical Society,164(4): 71-77. https://doi.org/10.1149/2.1211704jes

Louise, ISY. (2012). Studies on the Hydrogen Evolution Reaction on Fe-CoNi/Stainless Steel Electrode. IOSR Journal of Applied Chemistry, 3(1): 06-10. https://doi.org/10.9790/5736-0310610

Obaid, A. Y., El-Mossalamy, E. H., Al-Thabaiti, S. A., El-Hallag, I. S., Hermas, A. A., dan Asiri, A. M. (2014). Electrodeposition and Characterization of Polyaniline on 
Stainless Steel Surface Via Cyclic, Convolutive Voltammetry and SEM in Aqueous Acidic Solutions. International Journal of Electrochemical Science, 9(2): 1003-1015.

Okazaki, Y., \& Gotoh, E. (2008). Metal Release from Stainless Steel, Co-Cr-Mo$\mathrm{Ni}-\mathrm{Fe}$ and $\mathrm{Ni}-\mathrm{Ti}$ Alloys in Vascular Implants. Corrosion Science, 50(12): 3429-3438.

https://doi.org/10.1016/j.corsci.2008.09.0 02

Seyitoglu, S. S., Dincer, I., \& Kilicarslan, A. (2017). Energy and Exergy Analyses of Hydrogen Production by Coal Gasification. International Journal of Hydrogen Energy, 42(4): 2592-2600. https://doi.org/10.1016/j.ijhydene.2016.08 .228

Taveira, L. V, Frank, G., Strunk, H. P., \& Dick, L. F. P. (2005). The influence of Surface Treatments in Hot Acid Solutions on the Corrosion Resistance and Oxide Structure of Stainless Steels. Corrosion Science, 47: 757-769. https://doi.org/10.1016/j.corsci.2004.07.0 12

Xia, K., Zhan, H., \& Gu, Y. (2017). Graphene and Carbon Nanotube Hybrid Structure: A Review. Procedia IUTAM, 21: 94-101. https://doi.org/10.1016/j.piutam.2017.03. 042 